\title{
Organizations Endorsing the Statement On Faculty Status
}

The following organizations have endorsed the "Statement on Faculty Status of College and University Librarians," which appeared in the February 1974 issue of CRL News.

Association of College and

Research Libraries

Colorado Library Association December 1972

American Association of

University Professors

Wisconsin Association of

Academic Librarians

Maryland Library Association

Association of Academic and Research Librarians, Washington Library

Association

Southeastern Library Association

New Mexico Library Association

District of Columbia Library Association

Mississippi Library Association

West Virginia Library Association

Illinois Library Association

Tennessee Library Association

Virginia Library Association

Oregon Library Association

Southwestern Library

Association

Ohio Library Association

Florida Library Association

Missouri Library Association
April 1973

April 1973

April 1973

May 1973

July 1973

July 1973

July 1973

July 1973

July 1973

July 1973

August 1973

September 1973

September 1973

September 1973

September 1973

September 1973
July 1973
California Library Association September 1973 Special Libraries Association October 1973

North Dakota Library

Association

Association of Research Libraries"

October 1973

College and Research Section,

Kentucky Library Association October 1973

Wisconsin Library Association October 1973

College and University

Section, Georgia Library

Association

Georgia Library Association

Academic Division, Minnesota

Library Association

Theatre Library Association

Rhode Island Library

Association

October 1973

October 1973

October 1973

October 1973

College and University Section,

North Carolina Library

Association

November 1973

Kentucky Library Association December 1973

Association of American

Library Schools

January 1974

Music Library Association

January 1974

"VOTED "that the Board endorse in principle faculty status for professional librarians, and commend to the attention of all college and university administrations the "Joint Statement on Faculty Status of College and University Librarians." "

\section{Ten-Year Cumulation of Choice Announced}

The Association of College and Research Libraries announces the forthcoming publication of a ten-year cumulated and interpolated edition of Choice book reviews. This edition, containing approximately 58,000 Choice reviews arranged under an elaborate system of subject categories, will cover the first decade of the magazine (volumes I through 10, 1964-74). The edition will be published in 1975 by Rowman and Littlefield, of Totowa, New Jersey, publishers of the National Union Catalog, 1956-1967 and other bibliographic tools. It will appear in nine volumes, including a cumulated author-title-subject index, which will refer users to entries both in the original monthly issues of Choice and in this edition. The index will also include, for the first time, index entries to most works cited within the original reviews as well as to the reviews themselves. The index will be available with the complete set or as a separate volume. Prices will be announced.

Developed under the general supervision of Richard K. Gardner, editor of Choice, this tenyear edition will be edited by Phyllis $\mathrm{H}$. Grumm, a former reclassifier in Wesleyan University Library's six-year, 300,000-title Reclassification Project.

The Association of College and Research Libraries is proud to announce the publication of this substantial and significant work, which should find considerable favor within both the library and publishing worlds. 